\title{
Analysis of the ecological effectivness of passenger transport by jets of various sizes
}

The article's aim was to compare an ecological effectiveness of a common jetliner with 189 passenger capacity flying on two CFM engines and a very light jet business aircraft designed to carry up to 8 people on board. The carried-out analysis showed that the $\mathrm{NO}_{x}$ emission per passenger in Very Light Jet (VLJ) is three times higher than in common jet airliner, furthermore there is 15 times difference in $\mathrm{CO}$ emission. Based on the results of the analysis, it can be stated that it is appropriate to extend the certification of engines to smaller units, as well as to adjust the LTO test beyond laboratory conditions.

Keywords: LTO cycle, jet aircraft, air transport emission

\section{Introduction}

Aircrafts and airports air pollutant emissions has had the increase of interest since the growth in commercial turbojet traffic in the 1970s. The whole transport branch including air transport is a cause of environment degradation. Pollutions, as well as, noise effective badly on human health. Aircraft Emissions influence climate change by [1]:

- greenhouse gases emissions $\left(\mathrm{CO}_{2}\right.$ mainly),

- ozone precursors emission,

- particular matter emission,

- clouds making.

In 2016 aviation was accountable for $3.6 \%$ of the total greenhouse gas emission and for $13.4 \%$ of the emissions from transport. Emission standards are established for the control of pollutants emitted from aircrafts. Most airports also set the limits on carbon dioxide emissions, which are directly related to the payment of airport charges [2,11].

Regarding to emission factors for harmful compounds in the exhaust gas of aircraft engines, $\mathrm{CO}_{2}$ emissions increased from 88 to 156 million tonnes (by $77 \%$ ) between 1990 and 2005, but by only 5\% between 2005 and 2014 [10]. The increase in emissions is not so significant compared to the increase in the number of passengers in the same period of time (2005-2014), which is due to better quality of fuels and the replacement of the old fleet of aircraft with a newer one. During this period, the average amount of fuel consumed per passenger-kilometer in passenger planes (excluding private jets) decreased by $19 \%$. However, it is forecasted that the introduction of new technologies is not able to offset the effects of the growth of air traffic in the future and despite new technological solutions, an increase in $\mathrm{CO}_{2}$ emissions by $44 \%$ is expected (from 144 Mt in 2005 to $207 \mathrm{Mt}$ in 2035).

In the case of $\mathrm{NO}_{\mathrm{x}}$, a significant increase in their emissions can also be noted - by $85 \%$ (from 316,000 to 585,000 tonnes) between 1990 and 2005, and by $13 \%$ between 2005 and 2014 [10]. As in the case of $\mathrm{CO}_{2}$ emissions, further increases in $\mathrm{NO}_{\mathrm{x}}$ emissions are forecast despite the introduction of new construction solutions (constant introduction of a higher exhaust gas temperature before the high pressure turbine) - it is estimated that in $2035 \mathrm{NO}_{\mathrm{x}}$ emis- sion will reach 920,000 tonnes (what will be an increase of $42 \%$ compared to 2005$)$.

In the period 2005-2014, the emission of $\mathrm{HC}, \mathrm{CO}$ and non-volatile PM particles was noted, but an increase of $7 \%$ of volatile particulate matter. However, it is forcasted that the emission of all these compounds will increase over the next 20 years.

The number of flights increased by $8 \%$ between 2014 and 2017 , and grows by $42 \%$ from 2017 to 2040 in the most likely forecast. However, there is a growing trend of Passenger Load Factor (PLF). That trend means that the commercial airplanes are full in more than $80 \%$ (Fig. 1) and that affects on lowering the fuel consumption per passenger.

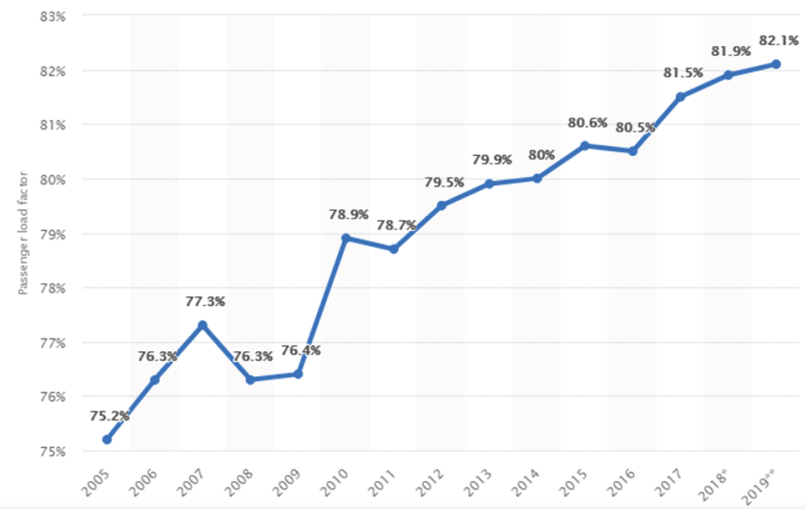

Fig. 1. Passenger Load Factor in commercial aircrafts worldwide since 2005 [13]

Although, the trend is positive, it can be noticed, that there is still some room for improvements.

There are number of emissions sources at the airports. They can be grouped in four categories:

- aircraft emission,

- aircraft handling emission,

- infrastructure or stationary- related sources,

- vehicle traffic sources.

In the article aircraft's main engine emission is taking into consideration [3-10]. 


\section{Landing and Take-Off cycle}

The emission of harmful exhaust gas compounds from combustion engines depends on operating conditions. The development of tests, aiming to assess pollutant emissions from various means of transport, is the key to minimize the human impact on the environment. An example of the test is LTO cycle mentioned in ICAO (International Civil Aviation Organization) Annex 16 about aircrafts' emission and noise. The LTO procedure was created to assess emission of harmful exhaust compounds from civil aircraft engines. The measurement is performed in stationary conditions. The flight of the aircraft is mapped by four phases: take-off $-100 \%$ Fc max (maximum thrust), climb $-85 \%$ of Fc max, approach $-30 \%$ of Fc max, taxiing $-7 \%$ of Fc max. Each of them has a different duration and power setting (Table 1). The whole test lasts about 30 minutes [12].

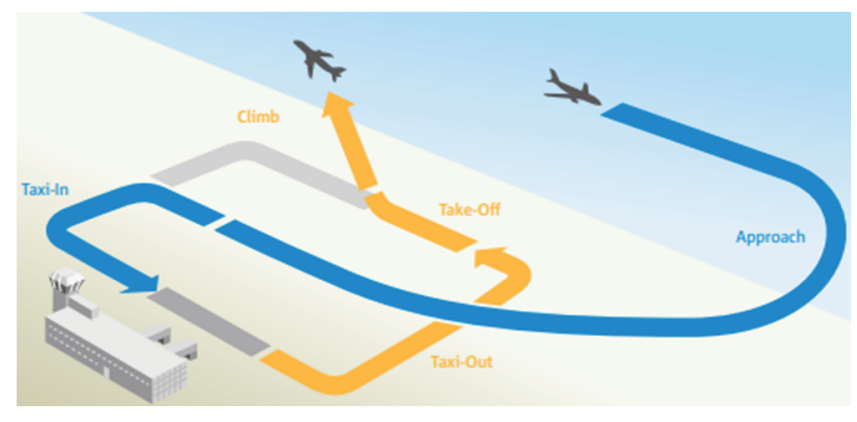

Fig 2. LTO cycle phases [14]

The durations of individual phase are proportional to the one in real conditions. The emission in LTO cycle is defined as mass of the harmful compound per mass of used fuel. Emission from one of aircraft's engines is a function of two parameters [9]: time-in-mode (TIM) - is the period that the aircraft engine actually spends at the specific power settings, main engine emissions indicate (EI) - the mass of pollutant emitted per unit mass of fuel burned for a specified engine. The EI for certified engines is provided by ICAO Engine Emissions Data Bank (EEDB) and fuel flow:

$$
\mathrm{EPC}=(\mathrm{TIM} \cdot 60) \cdot \mathrm{FFR} \cdot \mathrm{EF} \cdot \mathrm{NE}
$$

where: EPC - emissions per cycle for a particular mode [g/phase], TIM - Time in Mode [s/phase], FFR - fuel flow rate $[\mathrm{kg} / \mathrm{s}], \mathrm{EF}$ - emission factor $[\mathrm{g} \mathrm{kg}], \mathrm{NE}$ - number of enigines on aircraft [-].

The LTO cycle is used for aircrafts over $27.6 \mathrm{kN}$ of thrust and does not includes cruising phase above $3000 \mathrm{ft}$ (915 m) above ground level (AGL). Certification procedures are carried out on a single engine in a test cell, referenced to static sea level and International Standard Atmosphere (ISA) conditions. It is widely recognized that the ICAO standards used in certification vary from actual aircraft emissions that occur in specific locations and operational situations. With the development of aviation, the LTO test started to be carried out more often, but not for its' original purpose. A new aim was an assessment impact of aircraft movement on environment in airports area. The cycle consists of four model phases representing: taxiing, approaching, taking-off and climbing (Table 1).
Table 1. List of parameters in the LTO cycle

\begin{tabular}{|l|c|c|}
\hline Phase & Duration [min] & Power setting [\%] \\
\hline Approach & 4 & 30 \\
\hline Take-Off & 0.7 & 100 \\
\hline Climb & 2.3 & 85 \\
\hline Taxiing & $\begin{array}{c}26 \\
\text { (7 in, } 19 \text { out })\end{array}$ \\
\hline
\end{tabular}

Although, the LTO emission is an artificial model, created to certificate engines and the results are slightly different from real conditions, the test can be successfully used as a reference cycle to certify and demonstrate compliance with emission standards. Emission standards are covering $\mathrm{CO}, \mathrm{HC}, \mathrm{NO}_{\mathrm{x}}$ and smoke emission of subsonic, supersonic aircrafts with turbofan and turbojet engines greater than or equal to $26.7 \mathrm{kN}$ of thrust. Turboprop, piston, turboshaft engines and general aviation's aircrafts are excluded from standards due to its' small fuel usage compared to commercial het aircrafts. The certification data for $\mathrm{CO}, \mathrm{HC}$ and $\mathrm{NO}_{\mathrm{x}}$ all along with fuel flow rates are reported according to four different power settings (Table 1). However, smoke emissions are to be reported only as a maximum value of smoke density, reported as a smoke number for each engine. There are three possible approaches to the LTO cycle. The simple approach is the most elementary and requires publicly available data but provides the highest level of uncertainty which may results in overestimating the emission. The advanced approach takes into account specific information about the specific airport. Data needed are still publicly available but can be difficult to get. The most sophisticated approach is the best to obtain actual aircraft emission. It requires maximum amount of data available mainly to the aircraft user and wide analysis. It was notified, that the LTO cycle test results can vary with different operating times, power settings, airports, day-to-day, or even single day conditions for exactly the same type of aircraft. However, fixed conditions of LTO cycle provides a clear reference point from which differences in aircrafts emissions performance can be compared. Moreover, engine manufacturers always design their products for peak efficiency at delivery, as aircraft enter revenue service some performance degradation may be experienced over time due to the harsh environments aircraft and engines will operate in. Erosion, seal degradation and dirt build-up on finelytuned rotating hardware and airframes over long periods of time can lead to performance loss. If left unchecked, the deterioration can result in noticeable fuel consumption increases over time. Fuel consumption increases are an unnecessary cost increase to the carriers, and as a result they will normally perform maintenance on their products to keep the level of performance loss at acceptable levels.

\section{Analysis of jet aircrafts emission}

The model airplanes selected for the analysis are:

1. Medium-range, mid-size, narrow-body, twin-engine jetliner, constructed mostly of composite materials with CFM56-7B24 engines,

2. Small business jet with a maximum take-off weight of or under $5000 \mathrm{~kg}$ and approved for single-pilot operations. 
The aircrafts chose for the analysis are model ones, which means the calculations are suitable for a group of aircrafts, not a single one. For better understanding of the topic, examples have been used (Table 2).

Table 2. The comparison of two sample aircrafts $[15,16]$

\begin{tabular}{|l|c|c|}
\hline $\begin{array}{l}\text { Aircraft } \\
\text { type }\end{array}$ & Jetliner & VLJ \\
\hline $\begin{array}{l}\text { Aircraft } \\
\text { sample } \\
\text { model }\end{array}$ & Boeing 737 & Honda HA-420 \\
\hline $\begin{array}{l}\text { Unit cost } \\
\text { Wingspan }\end{array}$ & US\$ $100.5 \mathrm{million}$ & US\$ 4.9 million \\
\hline Range & $35.8 \mathrm{~m}$ & $12.1 \mathrm{~m}$ \\
\hline $\begin{array}{l}\text { Cruise } \\
\text { speed }\end{array}$ & $7408 \mathrm{~km}$ & $2234 \mathrm{~km}$ \\
\hline $\begin{array}{l}\text { Max. take- } \\
\text { off weight }\end{array}$ & $946 \mathrm{~km} / \mathrm{h}$ & $682 \mathrm{~km} / \mathrm{h}$ \\
\hline Engines & $78,245 \mathrm{~kg}$ & $4808 \mathrm{~kg}$ \\
\hline $\begin{array}{l}\text { Fuel } \\
\text { capacity }\end{array}$ & CFM56 & $1290 \mathrm{~kg}$ \\
\hline
\end{tabular}

The exhaust gas of turbine engines includes: nitrogen oxides $\left(\mathrm{NO}_{\mathrm{x}}\right)$, sulfur oxides $\left(\mathrm{SO}_{\mathrm{x}}\right)$, carbon dioxide $\left(\mathrm{CO}_{2}\right)$, carbon monoxide (CO), unburned hydrocarbons (UHC) and particulate matter (PM). These compounds, as a result of further photochemical reactions occurring in the atmosphere, cause a number of adverse phenomena (acid rain, photochemical smog, increased tropospheric ozone, etc.). For the purpose of analysis, $\mathrm{CO}$ and NOx were chosen. The emission factor and Fuel Flow Rate necessary to make calculations come from ICAO emission databank. The results of the calculations carried out are presented in the form of diagrams to show the dependencies. As it results from the calculations made, the NOx jetliner emission per passenger is about three times smaller, than VLJ emission, assuming that both model planes were full. Furthermore, the $\mathrm{CO}$ emission is nearly 15 times less (Fig. 2). The amount of passenger seats available in jetliner is 189 and in $\mathrm{VLJ}-8$ [11].

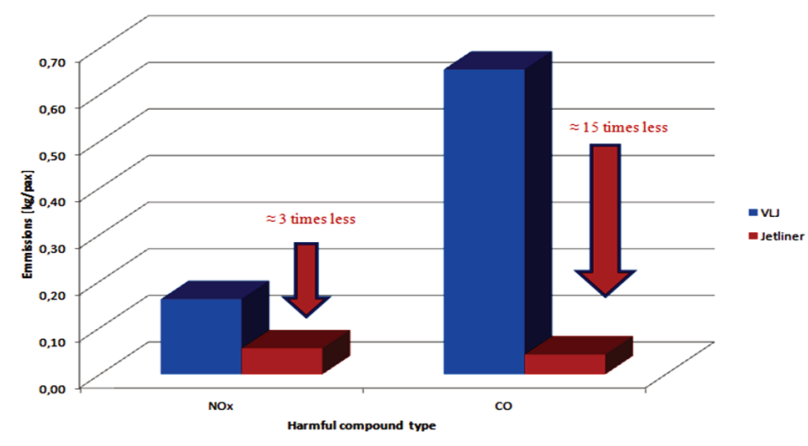

Fig. 3. Comparison between VLJ and jetliner's $\mathrm{CO}$ and NOx emission per passenger

Considering CO emission, it is ecologically advisable only to do VLJ flight up to 8 passengers. If there are more than 8 passengers, it is better to engage jetliner, because 2
VLJs emit more CO mass, than one jetliner (Fig. 4). It is optimistic from commercial airlines point of view. If the legislation is tightened, it is possible, that in the future businessmen will be forced to change into commercial aircraft.

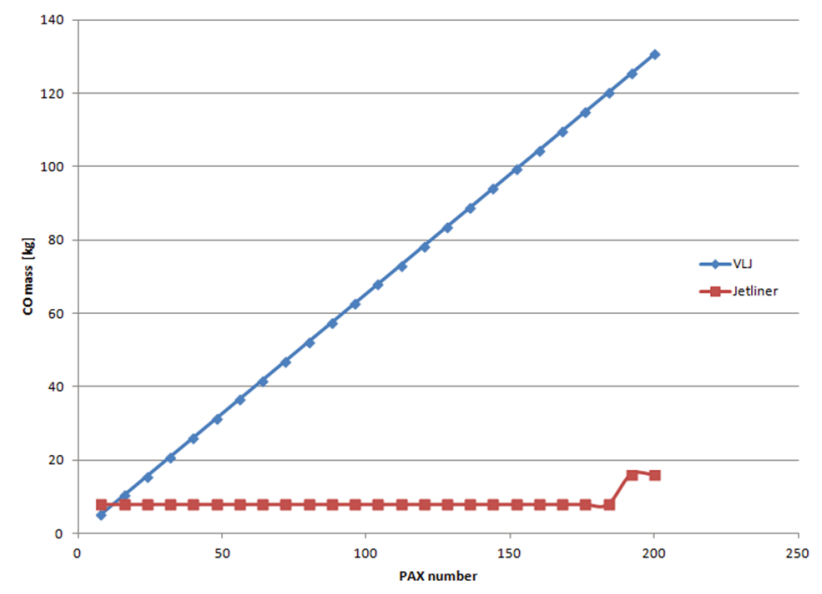

Fig. 4. Comparison between VLJ and jetliner's CO total emission per number of passengers

Analyzing the results considering $\mathrm{NO}_{\mathrm{x}}$ emission, as it can be noticed (Fig. 5) according to $\mathrm{NO}_{\mathrm{x}}$ emission it is better for ecological reasons to fly 8 VLJ with 8 people each than one jetliner with the same number of people on board. Even two jetliners capable of transporting 378 passengers are more ecologically efficient than 24 VLJs.

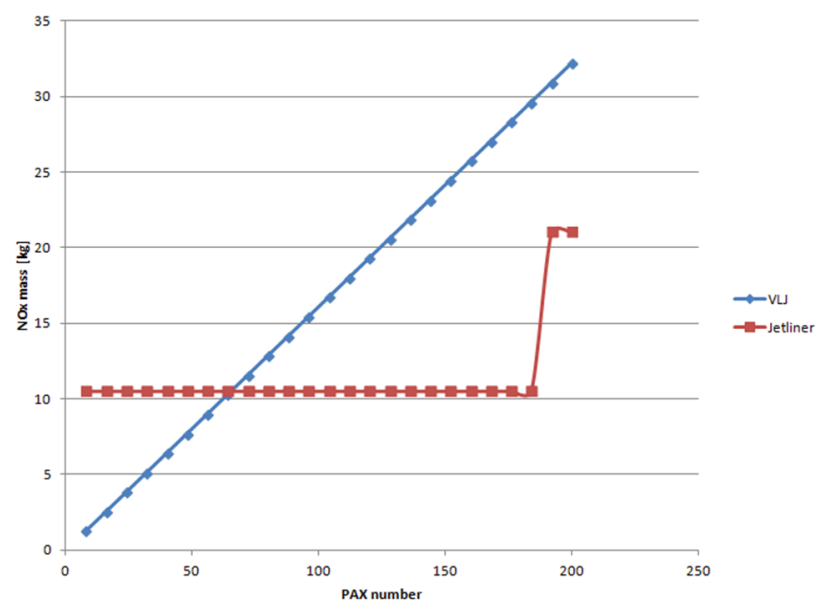

Fig. 5. Comparison between VLJ and jetliner's NOx total emission per number of passengers

Taking into consideration, that about $80 \%$ of aircrafts registered in USA are general aviation (for non-commercial purposes) it is advisable to extend the ICAO certification process and consider VLJ's engines in emission standards. Some of the airports around the world, especially big ones are charging aircraft carriers for their airplane's emission and noise. For example, at the Charles-de-Gaulle airport there are five emission classes and six acoustics groups of aircrafts (Fig. 6). 


\begin{tabular}{lcc}
\multicolumn{4}{l}{ Paris - Orly et Paris Charles-de-Gaulle } \\
\hline Acoustic group & $\begin{array}{c}\text { Day and evening } \\
(06 \mathrm{~h} 00-22 \mathrm{hOO})\end{array}$ & $\begin{array}{c}\text { Night } \\
(22 \mathrm{~h} 00-06 \mathrm{hO0})\end{array}$ \\
\hline Group 1 & 1.300 & 1.950 \\
\hline Group 2 & 1.200 & 1.800 \\
\hline Group 3 & 1.150 & 1.725 \\
\hline Group 4 & 1.000 & 1.500 \\
\hline Group 5a & 0.850 & 1.275 \\
\hline Group 5b & 0.700 & 1.050 \\
\hline
\end{tabular}

Fig. 6. Acoustic groups and charges for Paris Charles de Gaulle airport [17]

Due to ecological and social reasons, airport managers impose obligations on air operators to renew the fleet. Older, less effective, consuming more fuel airplanes are more expensive to operate. Bombardier DH8-Q400, ATR 42 I 72, Canadair Regional Jet CRJ-900 are among others in 1 class, which is the most expensive group. In 5th class there is only one airplane Airbus A380. Thus, it can be stated that exploiting the fleet consist of new aircrafts is not only advisable because of lower fuel consumption (A380 has a fuel consumption less than three liters per passenger per 100 kilometers) but also savings resulting from lower airport charges. Another way to reduce the adverse impact of airplanes on the natural environment is the appropriate shaping of flight routes, minimizing the emission of harmful compounds. This requires proper flight planning, taking into account the limitations resulting from the organization of the airspace and the rules in force there and current weather conditions. The weather is one of the most important factors affecting the amount of fuel used, time and cost of the flight. Also, from weather and altitude point of view it is better to fly higher, which effects in more stabilized weather conditions and less fuel consumption, further from the ground.

\section{Conclusions}

One of the solutions, which could have a positive impact for minimizing the fuel consumption rate per passenger is creating last minute first or business class option for businessmen. To encourage them to fulfill "empty legs", lower ticket prices and special, quick security control would be available for those who decides to exchange private jet for first or business class seat. Furthermore, it should be noted that the change in the time of individual phases of the LTO cycle has a significant impact on the volume of emissions from particular types of aircraft. For testing emission in airports areas, the adjustment should be done. Individual parameters should be special for each airport to get results much closer to the actual local emission. The differences are clearly visible for medium sized airports and for big ones they are significant. The two biggest programs established to limit the negative impact on the environment of air transport and cooperating industry are: SESAR 2020 and Clean Sky 2. First of them is to create new air traffic management solutions (what will diminish air transport impact on environment at about $10 \%$ ), the second program concentrates on state-of-the-art technological solutions (new airplanes, propulsions, avionics).

It should be remembered that emissions from airportrelated surface transportation can constitute a significant portion of the total emissions associated with airport activities. The stationary emission sources such as generators or heating plants emitting from fixed locations can not be forgotten either. There are more and more sophisticated ways to assess the air transport emission from the whole branch including the aircraft's engines on the construction stage, engines in use, stationary and movable equipment at the airport, as well as, airport's users and suppliers. There are special models possible to create in 3D technique, which enables the airport manager to asses and control the emission level during the airport opening hours. It is recommended to manage a comprehensive approach to the problem, so that the emission could be mitigated at every stage from aircraft designing and manufacturing, through ticket booking, to passengers' cars parking.

\section{Nomenclature}

AGL Above Ground Level

$\mathrm{CO}$ carbon monoxide

$\mathrm{CO}_{2} \quad$ carbon dioxide

EEDB Engines Emissions Data Bank

EU European Union

ICAO International Civil Aviation Organization

ISA International Standard Atmosphere

$\begin{array}{ll}\text { LTO } & \text { Landing and Take Off cycle } \\ \mathrm{NO}_{\mathrm{x}} & \text { nitrogen oxides } \\ \text { PLF } & \text { Passenger Load Factor } \\ \text { PM } & \text { particulate matter } \\ \text { TIM } & \text { time in mode } \\ \text { VLJ } & \text { Very Light Jet }\end{array}$

\section{Bibliography}

[1] International Civil Aviation Organization (ICAO). International Standards and Recommended Practices. Annex 16 to the Convention on International Civil Aviation - Environmental Protection. Aircraft Engine Emissions. 3rd edition. 2008, 2.

[2] MERKISZ, J., MARKOWSKI, J., ŚLUSARZ, G. et al. Comparative analysis of exhaust emission tests for a turbine engine. Combust. Engines. 2015, 162(3), 449-455.

[3] PAWLAK, M., MAJKA, A., KUŹNIAR, M., PAWLUCZY, J. Emission of selected exhaust compounds in jet engines of a jet aircraft in cruise phase. Combustion Engines. 2018,
57(2), 67-72.

[4] International Civil Aviation Organization (ICAO). Operational opportunities to minimize fuel use and reduce emissions Cir 303/AN176. 2003.

[5] MAJKA, A. Ekologiczne aspekty wspomagania startu samolotu systemem wykorzystującym zjawisko magnetycznej lewitacji. Logistyka. 2015, 4, 593-602.

[6] International Civil Aviation Organization (ICAO). Environmental Branch, ICAO Environmental Report 2016, aviation and climate change. 2016.

[7] EEA, EASA and Eurocontrol. European Aviation Environ- 
mental Report 2019. 2019.

[8] International Civil Aviation Organization (ICAO). Guidance on Aircraft Emissions Charges Related to Local Air Quality, Doc 9884. 2007.

[9] International Civil Aviation Organization (ICAO), Airport air quality manual. 2011.

[10] PAWLAK, M., KUŹNIAR, M. Problematyka emisji toksycznych składników splain silników lotniczych. Autobusy. 2017, 12, 338-344.

[11] NOWAK, M., JASIŃSKI, R., GALANT, M. Implementation of the LTO cycle in flight conditions using FNPT II
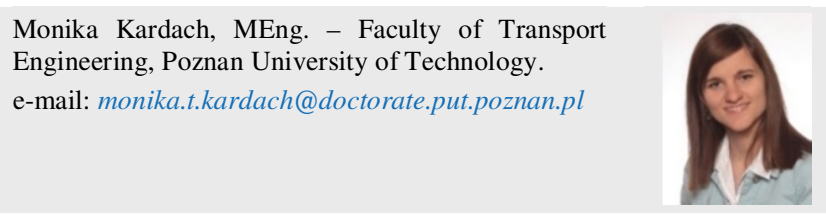

Paweł Fuc, DSc., DEng. - Faculty of Machines and Transport at Poznan University of Technology.

e-mail: pawel.fuc@put.poznan.pl
MCC simulator. IOP Conference Series: Materials Science and Engineering. 2018, 421, 10.

[12] MERKISZ, J., GALANT, M., KARIŃSKI, D., KUBIAK, K. Evaluation of possibility to use the LTO cycle for emission test on example of the model turbine engine GTM- 120 . J. Mech. Transp. Eng. 2014, 66(2), 25-33.

[13] www.statista.com

[14] www.easa.europa.eu

[15] www.boeing.com

[16] www.hondajet.com

[17] www.parisaeroport.fr

Marta Galant, DEng. - Faculty of Transport Engineering, Poznan University of Technology.

e-mail:marta.galant@put.poznan.pl 